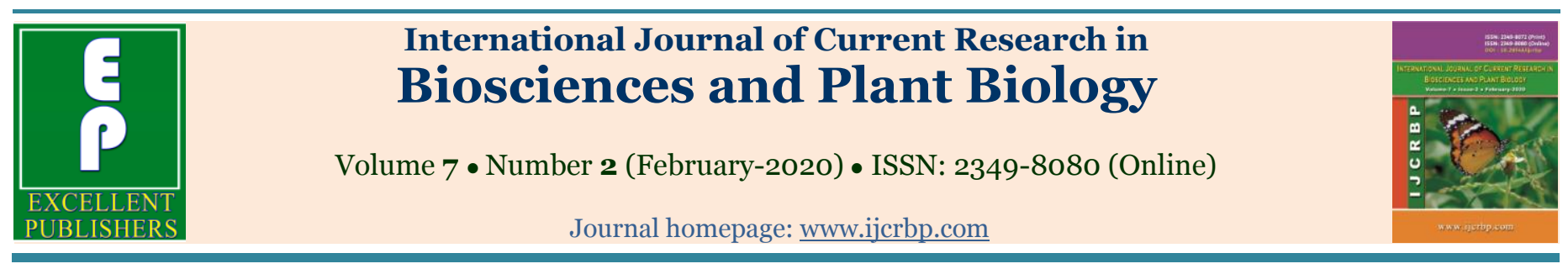

\title{
Integrated land suitability analysis of cacao (Theobroma cacao L.) using parametric and economic approach
}

\author{
R. Neswati ${ }^{*}$, M. Solle ${ }^{1}$, L. Asrul ${ }^{2}$, M. Mutawally3 and S. Nurqadri ${ }^{3}$ \\ ${ }^{1}$ Soil Science Department, Hasanuddin University, Indonesia \\ ${ }^{2}$ Agronomy Department, Hasanuddin University, Indonesia \\ 3 Post Graduate Program, Faculty of Agriculture, Hasanuddin University, Indonesia \\ *Corresponding author; e-mail: neswati76@gmail.com
}

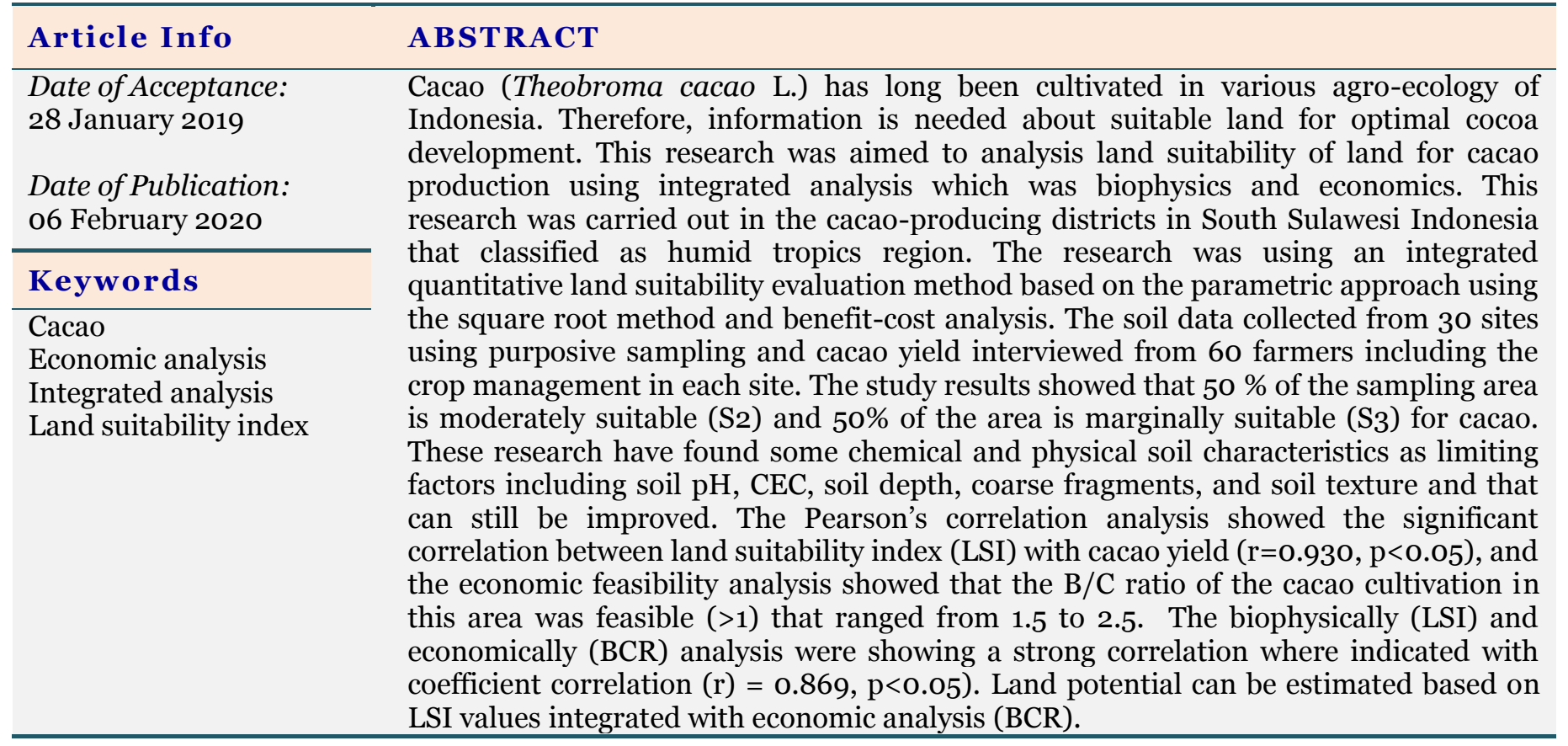

\section{Introduction}

In Indonesia, cacao is one of the prime plantations crops that grow along the tropical zones of Indonesia. Indonesia is the top three of the main cacao-producer in the world after Cote d'Ivore and Ghana (Mattyasovszky, 2018), but recently, the Indonesian cacao production becomes decrease until 12\% in 2018 (https://www.pertanian.go.id/,
2019). In this study, land suitability evaluation will emphasize the biophysical analysis of land for certain crop commodities which will ultimately determine the level of land productivity. Land evaluation is the process of estimating land potential to provide alternative land uses (Manikandan et al., 2013). The results of the land suitability assessment based on biophysical (climate, soil), socio-economic suitability and 
appropriate management support will provide optimal and sustainable results (Samanta et al., 2011; Rabia and Terribile, 2013; Seyedmohammadi et al., 2016). For LSI analysis will involve many land characteristics that control the capability of the land for specific purposes. Performing land suitability evaluation and generating maps of land suitability for different land-use types (Albaji et al., 2009) will facilitate to reach sustainable agriculture (Rabia and Terribile, 2013; Dengiz and Usul, 2018). According to Rabati et al. (2012), the accurate assessment methods (including biophysics, socio economic) will give better results and consequently support for improved management plan. This study examines land suitability evaluation for cacao in the humid tropics of Indonesia using an integrated quantitative approach based on the parametric approach and economic analysis.

\section{Materials and methods}

This research was carried out on District of Bantaeng, one of the cacao produce-area in South of Sulawesi, Indonesia (Fig. 1.) The study employed the integrated quantitative approach to analysis the land potential. Land suitability evaluation for cacao was performed using the land suitability index (LSI) analyzed with square root method (Khiddir, 1986) using equation (1) as below:

$$
L S I=R \min x \sqrt{\frac{A}{100} x \frac{B}{100}} x \frac{C}{100} x \ldots \ldots \ldots \ldots \ldots \ldots \ldots \text { Eq. (1) }
$$

Where LSI is land suitability index, Rmin is minimum land characteristic rating and A, B, C etc. are other ratings besides the minimum rating.

The suitability classes are defined according to the value of LSI by Sys et al. (1991) as expressed in Table 1.

Table 1. LSI values for different suitability class.

\begin{tabular}{lll}
\hline LSI & Suitability class & Definition \\
\hline $100-75$ & S1 & Highly suitable \\
$75-50$ & S2 & Moderately suitable \\
$50-25$ & S3 & Marginally suitable \\
$25-0$ & $\mathrm{~N}$ & Unsuitable \\
\hline Source: Sys et al. (1991) & &
\end{tabular}

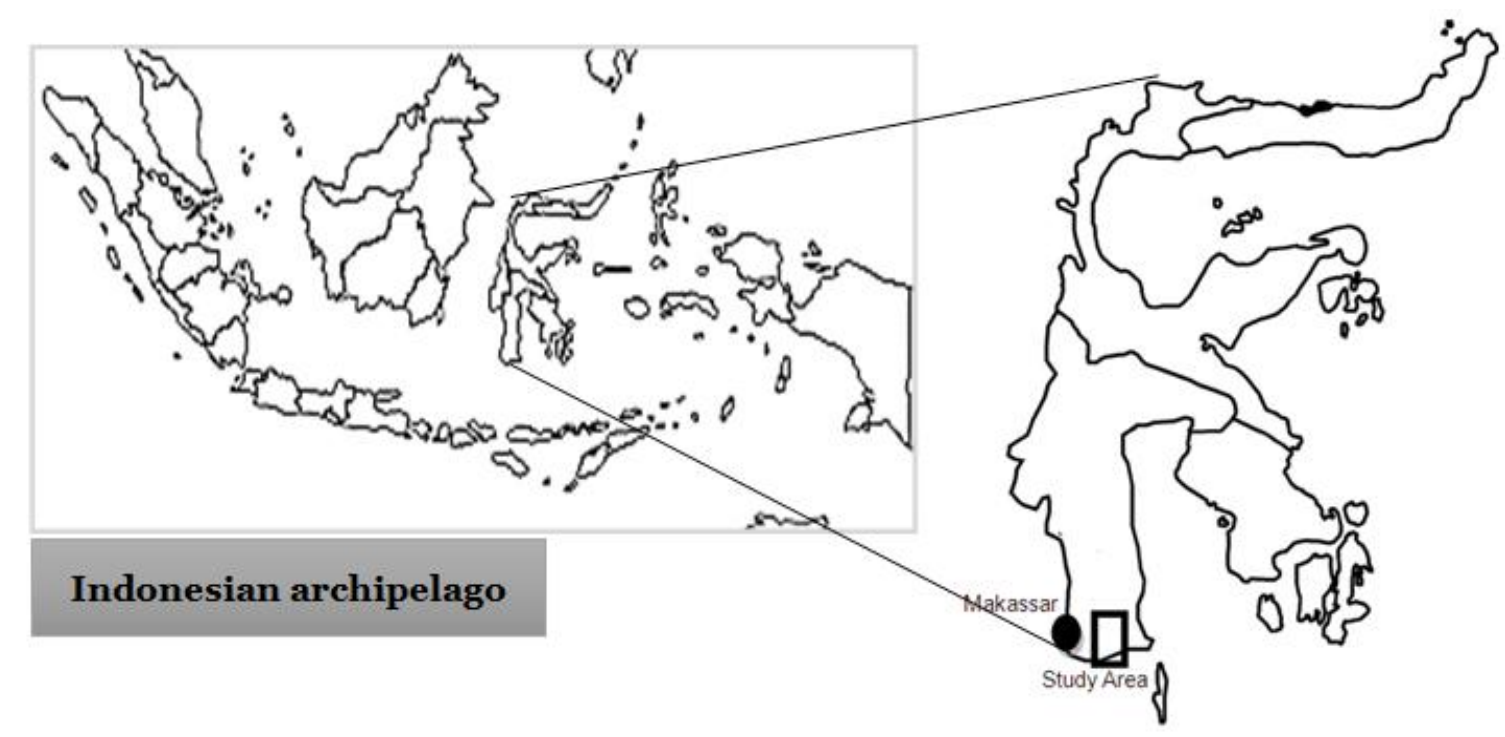

Fig. 1: Study Area at Sulawesi Island, Indonesia.

The simple economic analysis of cacao in the study area using benefit-cost ratio (BCR). The benefitcost ratio (BCR) is calculated as benefits divided by costs:

$$
B C R=\frac{\sum_{t=0}^{T} B t /(1+r)^{t}}{\sum_{t=0}^{T} C t /(1+r)^{t}}
$$
Equation (2) 
Where, $\mathrm{Bt}$ is the benefit at time $\mathrm{t}$ and $\mathrm{Ct}$ is the measure of costs at time t. If the BCR $>1$, then the project might be feasible.

This study covers survey activities and laboratory analysis, guided by Landon (1984). For soil classification using soil taxonomy system by Soil Survey Staff (2014). Field surveys were collected the actual performance of cacao that represents a wide range of physical environments within the study area that supported by interviewing cacao farmers each soil profile site. The correlation analysis between the LSI and the value of BCR with the actual cacao yield obtained in the field were carried out using Pearson's correlation analysis with correlation coefficient value $(r)=0<r<1$.c

\section{Results and discussion}

\section{Climate and terrain of study area}

According to Oldeman (1977), climate type of the study area classified as B2 type with 9 wet months and 2 dry months. The Oldeman was determined the climate types based on the month of the consecutive wet and dry consecutive month as well, when precipitation over $200 \mathrm{~mm}$ is a wet month and less than $100 \mathrm{~mm}$ is a dry month.

Several types of land use can be founded in the study area, including agroforestry cacao-based, cacao monoculture, shrubs, and dryland agriculture.

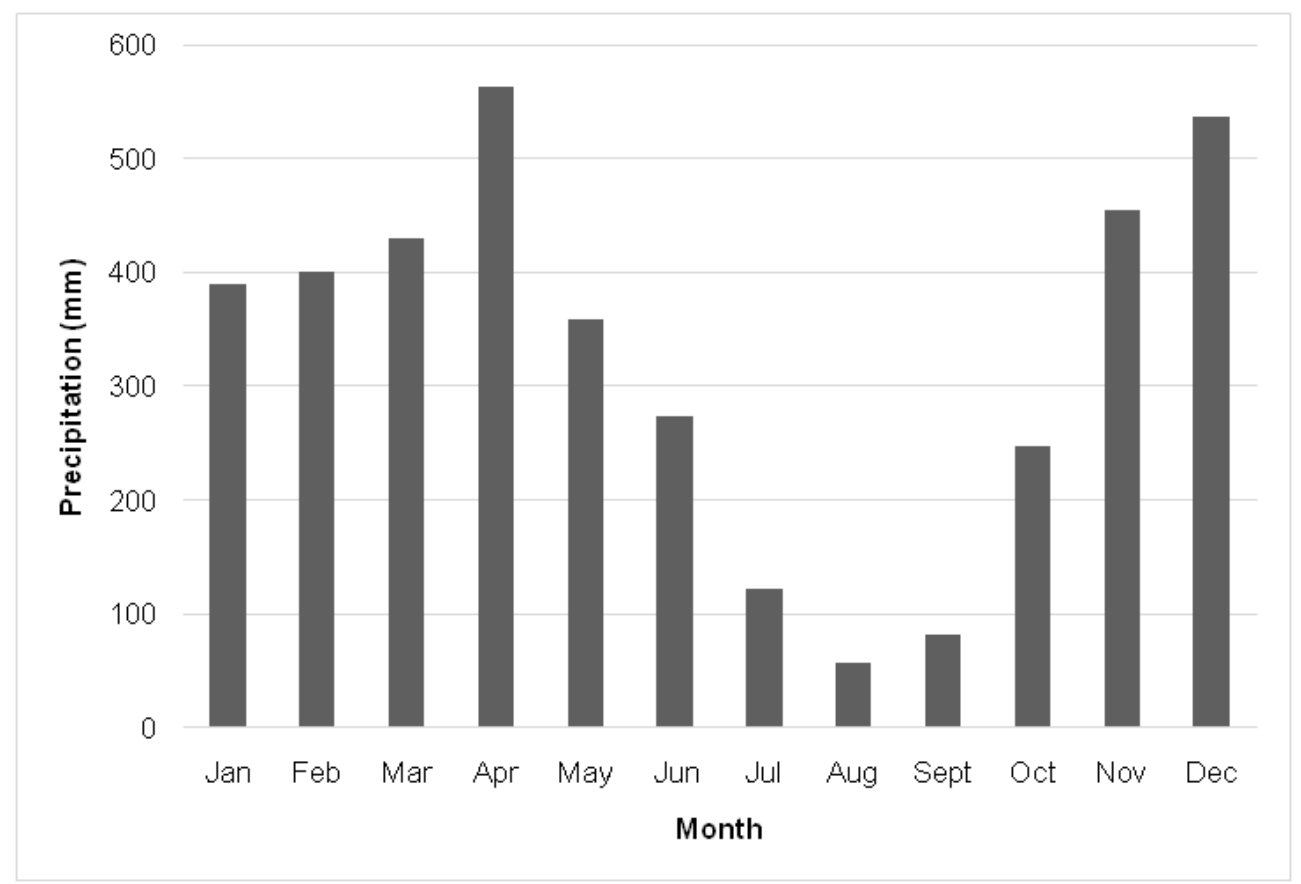

Fig. 2: The average of precipitation at study area (2009-2018).

Based on the soil taxonomy system (Soil Survey Staff, 1975; 2014), soils in the study site classified as Inceptisols, Alfisols, and Ultisols which were spread throughout the Bantaeng Regency. Inceptisols were found in the undulating area from the sandstone parent material. Alfisols were found in drier regions and form in alluvial in the flat regions. Ultisols were found in a more humid area, flat-wavy topography from the alluvial parent material. Alfisols are characterized by clay accumulation in the subsoil (argillic horizon), accumulation of high-activity clays (CEC $>24 \mathrm{cmol}$ $\mathrm{kg}^{-1}$ clay) and high base saturation (>50 \%) while
Ultisols have argillic with base saturation $<50 \%$ (Soil Survey Staff, 2014). According to FAO (2015), Ultisols and Alfisols ordo characterized by the development of structure, frequently with shiny aggregate faces (Fig. 3b and 3c). They formed from ultrabasic rocks or sediments derived under relatively intense weathering conditions in humid tropical regions. Therefore, many low activity clays, Fe-hydroxides and Al-hydroxides found it in this area. The dominant texture is clay loam or clay and the common structure are angular and/or subangular blocky. Fig. 3 shows the soil profile found in the study area. 

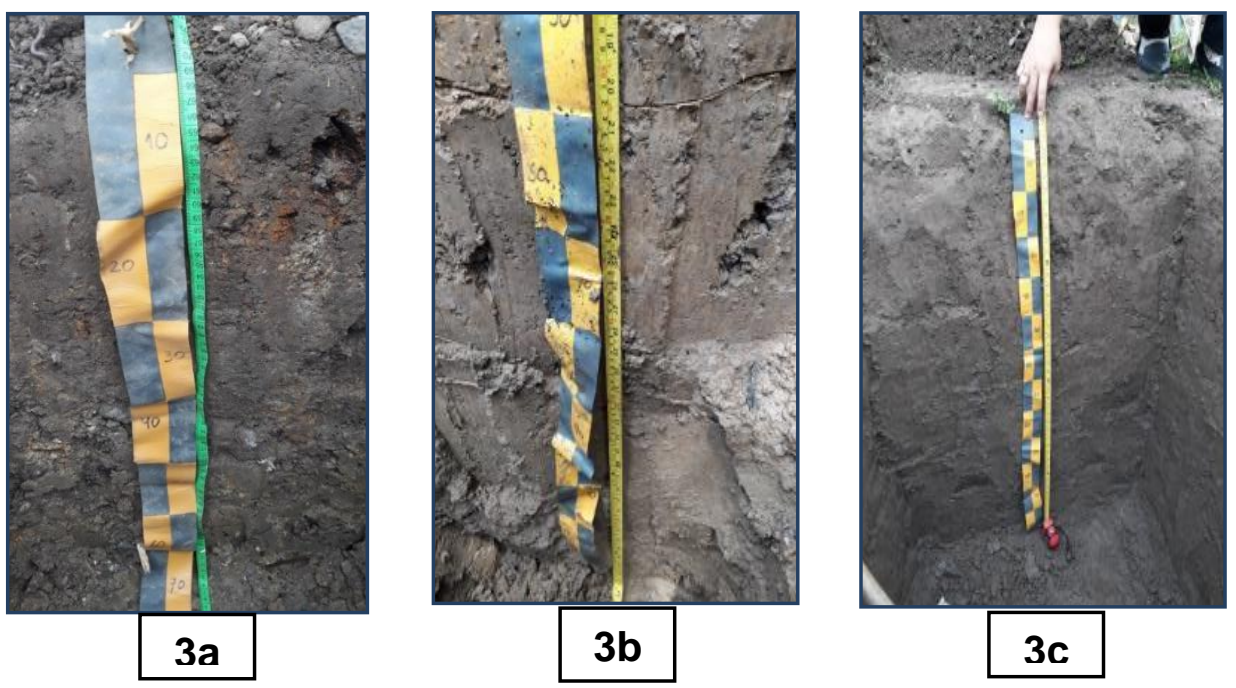

Fig. 3: (a) Inceptisols; (b) Alfisols; (c) Ultisols.

\section{Land suitability evaluation}

Land suitability analysis at 30 sites using the square root method showed that LSI ranges from 32 to 58 which classified as $\mathrm{S} 3$ and $\mathrm{S} 2$ respectively (see Table 2). Some soil characteristics become limiting factors for cacao in this area were climate, CEC, C-organic, soil texture, topography and soil pH. Based on Sys et al. (1991); (Rabia and Terribile, 2013); (Hopkins, 2007), the S1 (highly suitable) class refers to optimal yields (more than $75 \%$ of optimal, the $\mathrm{S} 3$ class to marginal yields (yields between 40 percent over and 10 percent below marginal), S2 has intermediary yields and has lower yields.

Table 2. LSI and subclass of study area.

\begin{tabular}{llllll}
\hline Site & LSI & Subclass & Site & LSI & Subclass \\
\hline 1 & 58 & S2c,f & 16 & 34 & S3f \\
2 & 55 & S2c,t & 17 & 32 & S3t,s \\
3 & 53 & S2c,f,t & 18 & 55 & S2c,f \\
4 & 49 & S3f,w & 19 & 41 & S3f,t \\
5 & 47 & S3f,s,w & 20 & 43 & S3f,s \\
6 & 46 & Sc,f,t & 21 & 54 & S2c,t \\
7 & 45 & S3s,t & 22 & 56 & S2c,f \\
8 & 52 & S2c,f & 23 & 58 & S2c,f \\
9 & 47 & S3f & 24 & 56 & S2c, w \\
10 & 47 & S3f,t & 25 & 40 & S3f,t \\
11 & 58 & S2c,f, s & 26 & 36 & S3f,t \\
12 & 47 & S3f,t & 27 & 58 & S2c,, \\
13 & 56 & S2c & 28 & 58 & S2c,f \\
14 & 38 & S3f,s & 29 & 56 & S2c,t \\
15 & 37 & S3f & 30 & 32 & S3f,w \\
\hline
\end{tabular}

Note: c: climate; f: soil fertility; t: topography; s: soil physics; w: wetness

In Table 2, the LSI values for the study areas ranging from 32 to 58 indicate that the study area has marginal land suitability classes to be moderately suitable for cocoa. This is in line with the results of cacao obtained, ranging from 0.5 to 1.o ( $\mathrm{t} \mathrm{ha}^{-1}$ ) (see Table 3) which is still below the value of the optimal yield. According to Bindraban et al. (2000); Verdoodt and Ranst (2003), in situations of potential crop production, the level of potential production can be achieved if plants are planted in a condition of adequate water and nutrient supply, pests and disease control (controlled). Temperature, radiation, $\mathrm{CO}_{2}$ and genetic characteristics of plants will determine the 
rate of plant growth. In situations of potential crop production, the level of potential production can be achieved if the plants are planted in a condition of sufficient water and nutrient supply, pest and disease control (controlled). Temperature, radiation, $\mathrm{CO}_{2}$ and genetic characteristics of plants will determine the rate of plant growth. Furthermore, to support the suitability analysis of cocoa land in the study area, an economic feasibility analysis of cocoa farming was collected from 60 cocoa farmers. The analysis shows that the average BCR value in the study area ranges from 0.7 to 2.5 (Table 3) which means that cocoa farming in the study area was partly classified as feasible because it has a BCR $>1$ and is not feasible because the BCR $<1$ (Shively, 2013).

Table 3. BCR, cacao yield and LSI of the cacao cultivation at the study area.

\begin{tabular}{llllllll}
\hline Site & LSI & Cacao yields $\left(\mathrm{t} \mathrm{ha}^{-1}\right)$ & BCR & Site & LSI & Cacao yields $\left(\mathrm{t} \mathrm{ha}^{-1}\right)$ & BCR \\
\hline 1 & 58 & 1.0 & 2.4 & 16 & 34 & 0.5 & 1.0 \\
2 & 55 & 0.9 & 2.0 & 17 & 32 & 0.5 & 1.0 \\
3 & 53 & 0.8 & 2.0 & 18 & 55 & 0.9 & 2.5 \\
4 & 49 & 0.8 & 1.2 & 19 & 41 & 0.6 & 1.0 \\
5 & 47 & 0.7 & 1.1 & 20 & 43 & 0.5 & 1.2 \\
6 & 46 & 0.7 & 1.0 & 21 & 54 & 1.0 & 2.4 \\
7 & 45 & 0.6 & 1.1 & 22 & 56 & 1.0 & 2.5 \\
8 & 52 & 0.9 & 1.9 & 23 & 58 & 1.0 & 2.0 \\
9 & 47 & 0.6 & 1.2 & 24 & 56 & 0.8 & 1.0 \\
10 & 47 & 0.6 & 1.1 & 25 & 40 & 0.6 & 1.0 \\
11 & 58 & 1.0 & 2.5 & 26 & 36 & 0.5 & 2.3 \\
12 & 47 & 0.6 & 1.1 & 27 & 58 & 1.0 & 2.2 \\
13 & 56 & 0.9 & 1.9 & 28 & 58 & 1.0 & 2.1 \\
14 & 38 & 0.6 & 1.0 & 29 & 56 & 0.9 & 1.0 \\
15 & 37 & 0.5 & 1.0 & 30 & 32 & 0.5 & \\
\hline
\end{tabular}

\section{Correlation analysis between LSI with cacao yield and BCR}

The Pearson's correlation analysis between LSI and cacao yields showed that a positive significant relationship as indicated by the Pearson's correlation coefficient $\mathrm{r}=0.930^{*}$; $\mathrm{p}<0.05$ (Fig. 4). The correlation analysis results indicate that along with the increase in LSI values, it was accompanied by an increase in cacao yields.

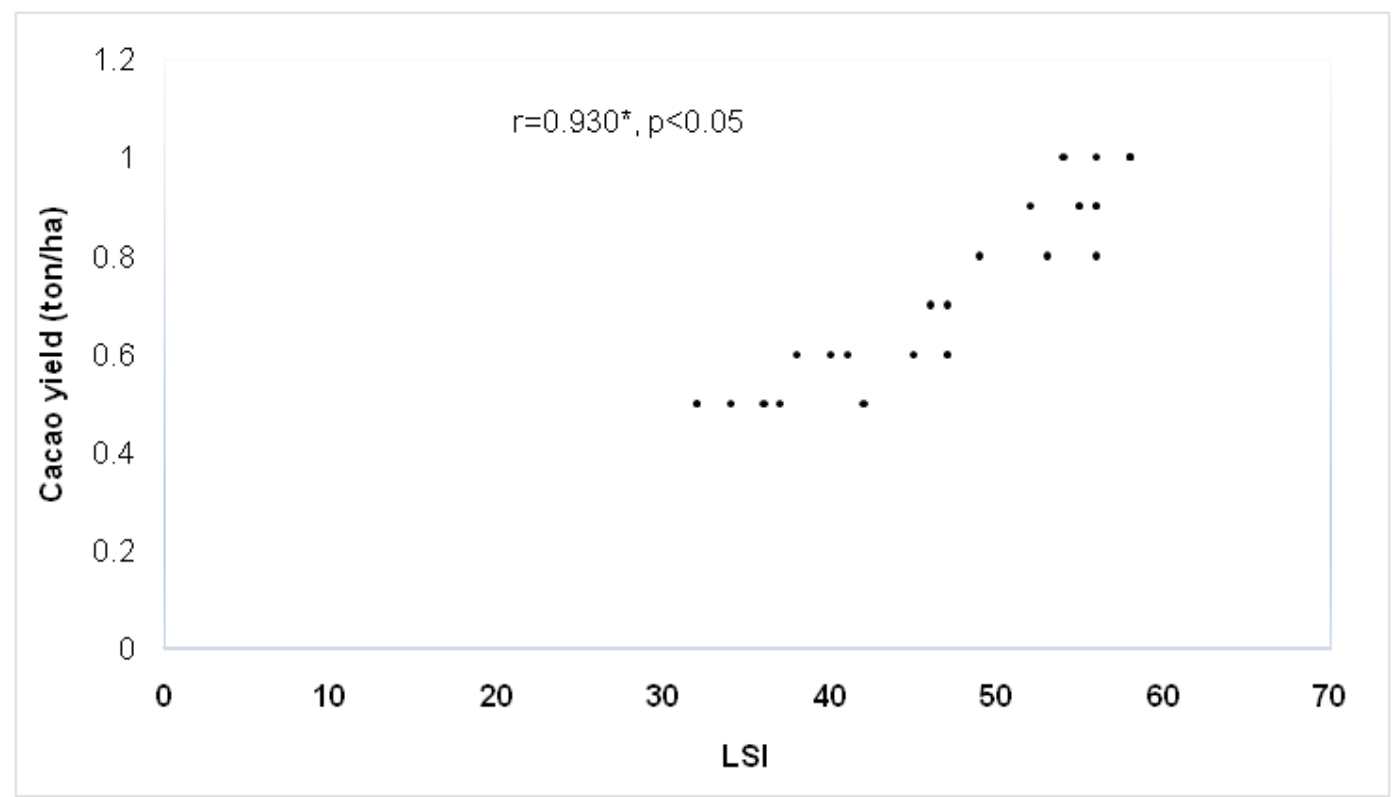

Fig. 4: The correlation between LSI with cacao yield. 
The results of the analysis show the LSI values at all observation sites are classified as $\mathrm{S}_{3}$ (marginal suitable) and S2 (moderately suitable) where according to Sys et al. (1991) and Rabia and Terribile (2013) marginal yield reflected the level of productivity and the total profit was in equilibrium with total expenses. If the optimal yield for cacao is $2 \mathrm{t} \mathrm{ha}^{-1}$ (Sys et al., 1993), then cacao predicted yield for marginal is $0.8\left(\mathrm{t} \mathrm{ha}^{-1}\right)$, which means BCR = 1 (Zali Vargahan et al., 2011), and for moderately suitable (S2) is $1.5 \mathrm{t} \mathrm{ha}^{-1}$. To determine the correlation between LSI and BCR in all units using Pearson correlation analysis was performed as shown in Figure 5. The analysis showed that the value of $\mathrm{r}=0.869 *(\mathrm{p}<0.05)$ which means there are strong correlations between LSI and BCR at the study site. This means that along with the increase in the value of LSI it will also be accompanied by an increase of cacao yield.

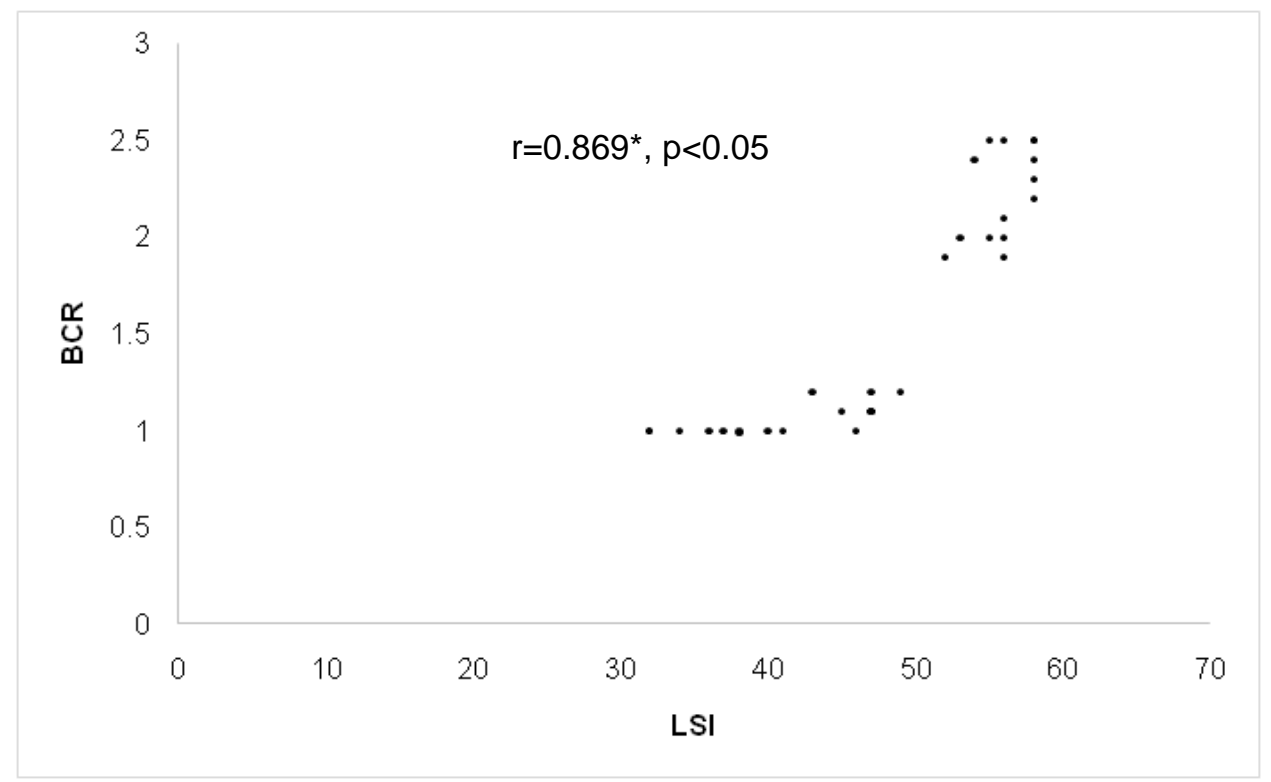

Fig. 5: The correlation between LSI with BCR.

\section{Conclusion}

Land potential can be estimated based on LSI values integrated with economic analysis (BCR). The LSI analysis results showed the location of the study had the potential to produce cacao $>0.8 \mathrm{t} \mathrm{ha}^{-1}$ with a BCR value $\geq 1$. The results of the analysis of potential development areas for cacao cultivation show that are suitable (at $\mathrm{S} 2$ and $\mathrm{S}_{3}$ classes) with land suitability index ranged from 32 to 58 .

\section{Conflict of interest statement}

Authors declare that they have no conflict of interest.

\section{Acknowledgement}

The authors are thankful to the LPPM Hasanuddin University Indonesia for providing research funds by Penelitian Dasar Unhas (PDU) scheme and Soil Science Department, Faculty of Agriculture, Hasanuddin University for providing many soil data for support this research.

\section{References}

Albaji, M., Naseri, A. A., Papan, P., Nasab, S. B., 2009. Qualitative evaluation of land suitability for principal crops in the west shoush plain, Southwest Iran. Bulgarian J. Agric. Sci. 15(2): 135-145.

Bindraban, P.S., Stoorvogel, J.J., Jansen, D.M., Vlaming, J., Groot, J.J.R., 2000. Land quality indicators for sustainable land management: Proposed method for yield gap analysis and soil nutrient balance. Agric. Ecosyst. Environ. 81, 103-112.

Dengiz, O., Usul, M., 2018. Multi-criteria approach with linear combination technique and 
analytical hierarchy process in land evaluation studies. Eur. J. Soil Sci. 7(1), 20-29.

FAO, 2015. World's Soil Resources. In: Status of the World's Soil Resources. https://doi.org /978-92-5-109004-6; https://www.pertanian. go.id/home/index.php?show=repo\&fileNum $=2$ o9 (accessed 15 August 2019)

Hopkins, L. D., 2007. Land suitability analysis : methods and interpretation Land Suitability Analysis: Methods and Interpretation. (November 2014), 41-43. https://doi.org/ 10.1080/01426397908705922

Khidir, S.M., 1986. A statistical approach in the use of parametric systems applied to the FAO framework for land evaluation. PhD Thesis of State University, Ghent, Belgium

Landon, J.R., 1984. Booker Tropical Soil Manual; A handbook for soil survey and agricultural land evaluation in the tropics and subtropics. Longman Inc, New York. 45op.

Manikandan, K., Kannan, P., Sankar, M., Vishnu, G., 2013. Concepts on land evaluation. Earth Science India, (Popular Issue VI (I)), 20-26.

Mattyasovszky, M., 2018. Top 10 Cocoa Producing Countries. Worldatlas. Retrieved from https:// www.worldatlas.com/articles/top-10-cocoaproducing-countries.html

Oldeman, 1977. The Agroclimatic Map of Sulawesi. Contr. Centr. Res. Ins. Agric. Bogor. No. 33. 30 p. map.

Rabati, A. P., Jafarzadeh, A. A., Shahbazi, F., Rezapour, S., Momtaz, H. R., 2011. Qualitative and quantitative land- suitability evaluation for sunflower and maize in the north-west of Iran. Arch. Agron. Soil Sci. 58(11), 1229-1242.

Rabia, A. H., Terribile, F., 2013. Introducing a New Parametric Concept for Land Suitability Assessment. (June 2014). https://doi.org/ 10.7763/IJESD.2013.V4.295
Samanta, S., Pal, B., Pal, D. K., 2012. Land Suitability Analysis for Rice Cultivation Based on Multi-Criteria Decision Approach through GIS. (January).

Seyedmohammadi, J., Esmaeelnejad, L., Ramezanpour, H., 2016. Land suitability assessment for optimum management of water consumption in precise agriculture. Model. Earth Syst. Environ. 2(3), 1-11.

Shively, G., 2013. An Overview of Benefit-Cost Analysis by. Accessed Online at Http://Www. Agecon. Purdue. Edu/Staff/Shively/COURSES /AGEC406/Reviews/Bca.Htm, (September), 1-8.

Soil Survey Staff, 2014. Keys to Soil Taxonomy. Twelfth Edition. United States Department of Agriculture, Natural Resources Conservation Service.

Sys, C., Van Sys, C., Van Ranst, E., Debaveye, J. 1993. Crop Requirements. Part III. Principles in Land Evaluation and Crop Production Calculations. Agricultural Publications No. 7. General Administration for Development Cooperation. Brussel-Belgium.

Sys, C., Van Sys, C., Van Ranst, E., Debaveye, J., 1991. Land Evaluation. Part I. Principles in Land Evaluation and Crop Production Calculations. Agricultural Publications No. 7. General Administration for Development Cooperation. Brussel-Belgium.

Verdoodt, A., Van Ranst, E., 2003. Land Evaluation for Agricultural Production in The Tropics. Ghent University. Laboratory of Soil Science. Gent, Belgium.

Zali Vargahan, B., Shahbazi, F., Hajrasouli, M., 2011. Quantitative and qualitative land suitability evaluation for maize cultivation in Ghobadlou Region, Iran. Ozean J. Appl. Sci. 4(1), 91-104.

\section{How to cite this article:}

Neswati, R., Solle, M., Asrul, L., Mutawally, M., Nurqadri, S., 2020. Integrated land suitability analysis of cacao (Theobroma cacao L.) using parametric and economic approach. Int. J. Curr. Res. Biosci. Plant Biol. 7(2), 7-13. doi: https://doi.org/10.20546/ijcrbp.2020.702.002 